\title{
Antibacterial activity and synergistic effects between Macbilus thunbergii ethanol extract and antibiotics against oral pathogens
}

\author{
Eun-Jin Jang ${ }^{1}$, Sung-Mi Choi ${ }^{2}$ and Jeong-Dan Cha ${ }^{3 *}$ \\ ${ }^{1}$ Department of Dental Technology, Daegu Health College, Daegu, Republic of Korea \\ ${ }^{2}$ Department of Dental Hygiene, Daegu Health College, Daegu, Republic of Korea \\ ${ }^{3}$ Material Development Team, R\&D Center, General Bio Co., Ltd. Namwon-si, Republic of Korea
}

\begin{abstract}
The cortex of Machilus thunbergii, which has been consumed as traditional herbal medicine for treatment of leg edema and abdominal distension and pain for a long period of time. In this study, the combination effect of $M$. thunbergii ethanol extract (MTEE) was evaluated against oral bacteria, either alone or with antibiotics, via broth dilution method and checkerboard and time kill assay. MIC/MBC values for MTEE against all the tested bacteria ranged between $12.5-50 / 50-200$ microg/ $\mathrm{mL}$, for ampicillin $0.0625-8 / 0.125-32 \mathrm{microg} / \mathrm{mL}$ and for gentamicin 4-128/8-512 microg/mL respectively. Furthermore, the $\mathrm{MIC}$ and $\mathrm{MBC}$ were reduced to one half-eighth as a result of the combination of MTEE with antibiotics. 1-6 hours of treatment with 1/2 MIC of MTEE with 1/2 MIC of antibiotics resulted from an increase of the rate of killing in units of $\mathrm{CFU} / \mathrm{mL}$ to a greater degree than was observed with alone. These results suggest that the MTEE is important in the antibacterial actions of oral pathogens agents.
\end{abstract}

\begin{abstract}
Abbreviations: MTEE: Machilus thunbergii ethanol extract; MICs: Minimum inhibitory concentrations; MBCs: Minimum bactericidal concentrations; CFU: Colony Forming Unit; FIC index: Fractional Inhibitory Concentration; FBC index: Fractional Bactericidal Concentration index.
\end{abstract}

\section{Introduction}

Oral disease is one of the most important preventable infectious diseases, a major health problem in dental caries and periodontal disease $[1,2]$. Oral health affects the general quality of life and poor oral health is associated with chronic conditions and systemic diseases [3-5]. There are more than 750 bacteria in the oral cavity, many of which are related to oral diseases [6]. The development of dental caries includes acidogenic and aciduric gram-positive bacteria, mainly mutans streptococci (Streptococcus mutans and S. sobrinus), lactobacilli and actinomycetes, which metabolize sucrose into organic acids that dissolve the calcium phosphate in teeth, causing decalcification and eventual decay [6-8]. In contrast, periodontal disease is subgingival and gum diseases associated with anaerobic gram-negative bacteria such as Porphyromonas gingivalis, Actinobacillus sp., Prevotella sp., and Fusobacterium sp. [9-11]. In periodontal disease, gingival crevices or areas beneath the gingiva are infected, causing cellular inflammatory response of the gingiva and surrounding connective tissue $[10,11]$. These inflammatory reactions can be caused by gingivitis (extremely common and seen as bleeding of the gingival or gum tissues) or periodontitis (the inflammatory response results in loss of collagen attachment of the tooth to the bone and in loss of bone) [12-14].

Many plant-derived medicines used in traditional medicinal systems have been documented in pharmacopeias for the treatment of infections and a number of these have been recently proved effective against oral microbial pathogens [15-18]. Machilus thunbergii (Lauraceae) is widely distributed in Korea. The cortex of M. thunbergii, which has been consumed as traditional herbal medicine for treatment of leg edema and abdominal distension and pain for a long period of time [19-21]. Isoquinoline alkaloids have been obtained from the root, lignin, catechin and polysaccharides from the heartwood, polysaccharides, and essential oils from the leaves, volatile components from the fruits, and lignans and neolignans from the cortex [22-24]. Some of these compounds are antioxidants with hepatoprotective, and anti-bacterial activities, while a few other show inhibitory effects on nitric oxide synthesis inactivated macrophages and neuroprotective activity against glutamate-induced neurotoxicity $[22,25,26]$. Machilin A (MA), one of the lignans shows biological activities, including stimulation of osteoblast differentiation via activation of p38 mitogenactivated protein(MAP) kinases in an in vitro osteoblasts [20].

In this study, we investigated the synergistic antibacterial activity of $M$. thunbergii ethanol extract (MTEE) in combination with existing antimicrobial agents against oral bacteria.

${ }^{\star}$ Correspondence to: Jeong-Dan Cha, Research Manager, Material Development Team, R\&D Center, General Bio Co., Ltd., 254 Yongtusna-ro, Songdong-myeon, Namwon-si, Jeollabuk-do, 55793 Republic of Korea, Tel. +82-63-263-0001, Fax: +82-70-5101-1563, E-mail: cjd@generalbio.co.kr

Key words: machilus thunbergii, antibacterial activity, oral pathogen bacteria, synergistic effect, minimum inhibitory concentrations (MICs), minimum bactericidal concentrations (MBCs)

Received: November 06, 2018; Accepted: November 22, 2018; Published: November 27, 2018 


\section{Materials and methods}

\section{Bacterial strains}

The oral bacterial strains used in this study were: Streptococcus mutans ATCC 25175, Streptococcus sanguinis ATCC 10556, Streptococcus sobrinus ATCC 27607, Streptococcus ratti KCTC (Korean collection for type cultures) 3294, Streptococcus criceti KCTC 3292, Streptococcus anginosus ATCC 31412, Streptococcus gordonii ATCC 10558, Aggregatibacter actinomycetemcomitans ATCC 43717, Fusobacterium nucleatum ATCC 10953, Prevotella intermedia ATCC 25611, and Porphylomonas gingivalis ATCC 33277. Brain-Heart Infusion (Difco Laboratories, Detroit, MI) broth supplemented with $1 \%$ yeast extract (Difco) was used for all bacterial strains except $P$. intermedia and $P$. gingivalis. For $P$. intermedia and $P$. gingivalis, $\mathrm{BHI}$ broth containing hemin $1 \mu \mathrm{g} / \mathrm{mL}$ (Sigma, St. Louis, MO, USA) and menadione $1 \mu \mathrm{g} / \mathrm{mL}$ (Sigma) was used.

\section{Minimum inhibitory concentrations/minimum bactericidal concentrations assay}

The minimum inhibitory concentrations (MICs) were determined for $M$. thunbergiii ethanol extract (MTEE) by the broth dilution method, and were carried out in triplicate (27). The antibacterial activities were examined after incubation at $37^{\circ} \mathrm{C}$ for $18 \mathrm{~h}$ (facultative anaerobic bacteria), for $24 \mathrm{~h}$ (microaerophilic bacteria), and for 1-2 days (obligate anaerobic bacteria) under anaerobic conditions. MICs were determined as the lowest concentration of test samples that resulted in a complete inhibition of visible growth in the broth. $\mathrm{MIC}_{50} \mathrm{~s}$ and $\mathrm{MIC}_{90} \mathrm{~s}$, defined as MICs at which, 50 and $90 \%$, respectively of oral bacteria were inhibited, were determined. Following anaerobic incubation of MICs plates, the minimum bactericidal concentrations (MBCs) were determined on the basis of the lowest concentration of MTEE that kills $99.9 \%$ of the test bacteria by plating out onto each appropriate agar plate. Ampicillin (Sigma) and gentamicin (Sigma) were used as standard antibiotics in order to compare the sensitivity of MTEE against oral bacteria.

\section{Checker-board dilution test}

The antibacterial effects of a combination of MTEE, which exhibited the highest antimicrobial activity, and antibiotics were assessed by the checkerboard test as previously described (27). The antimicrobial combinations assayed included MTEE with ampicillin or gentamicin. Serial dilutions of two different antimicrobial agents were mixed in cation-supplemented Mueller-Hinton broth. After 24-48 h of incubation at $37^{\circ} \mathrm{C}$, the MICs were determined to be the minimal concentration at which there was no visible growth and MBCs were determined on the basis of the lowest concentration of MTEE that kills $99.9 \%$ of the test bacteria by plating out onto each appropriate agar plate. The fractional inhibitory concentration (FIC)/ fractional bactericidal concentration (FBC) index was calculated according to the equation: FIC/FBC index $=\mathrm{FIC} / \mathrm{FBC}_{\mathrm{A}}+\mathrm{FIC} / \mathrm{FBC}_{\mathrm{B}}=(\mathrm{MIC} / \mathrm{MBC}$ of drug $\mathrm{A}$ in combination/ $\mathrm{MIC} / \mathrm{MBC}$ of drug $\mathrm{A}$ alone)+(MIC/MBC of drug $\mathrm{B}$ in combination/ $\mathrm{MIC} / \mathrm{MBC}$ of drug $\mathrm{B}$ alone). The FIC and FBC index are the sum of the FICs and FBCs of each of the drugs, which in turn is defined as the MIC and $\mathrm{MBC}$ of each drug when it is used in combination divided by the MIC and MBC of the drug when it is used alone. The interaction was defined as synergistic if the FIC and FBC index was less than or equal to 0.5 , additive if the FIC and FBC index was greater than 0.5 and less than or equal 1.0, indifferent if the FIC and FBC index was greater than 1.0 and less than or equal to 2.0, and antagonistic if the FIC and FBC index was greater than $2.0(27)$.

\section{Time-kill curves}

Bactericidal activities of the drugs under study were also evaluated using time-kill curves on oral bacteria. Tubes containing MuellerHinton supplemented to which antibiotics had been added at concentrations of the $\mathrm{MIC}_{50}$ were inoculated with a suspension of the test strain, giving a final bacterial count between $5 \sim 6.6 \times 10^{6} \mathrm{CFU} / \mathrm{ml}$. The tubes were thereafter incubated at $37^{\circ} \mathrm{C}$ in an anaerobic chamber and viable counts were performed at $0,0.5,1,2,3,4,5,6,12$ and $24 \mathrm{~h}$ after addition of antimicrobial agents, on agar plates incubated for up to $48 \mathrm{~h}$ in anaerobic chamber at $37^{\circ} \mathrm{C}$. Antibiotic carryover was minimized by washings by centrifugation and serial 10 -fold dilution in sterile phosphate-buffered saline, $\mathrm{pH}$ 7.3. Colony counts were performed in duplicate, and means were taken. The solid media used for colony counts were $\mathrm{BHI}$ agar for streptococci and $\mathrm{BHI}$ agar containing hemin and menadione for P. intermedia and P. gingivalis.

\section{Results and discussion}

\section{Minimum inhibitory concentrations/minimum bactericidal concentrations of MTEE and antibiotics}

MTEE evaluated the antimicrobial activities against eleven bacterial species present in the oral cavity.

The results of the antimicrobial activity showed that MTEE exhibited antimicrobial activities against cariogenic bacteria (MICs, 12.5 to $50 \mu \mathrm{g} /$ $\mathrm{mL}$; MBCs, 50 to $200 \mu \mathrm{g} / \mathrm{mL}$ ), against periodontopathogenic bacteria (MICs, 25 to $50 \mu \mathrm{g} / \mathrm{mL}$; MBCs, 50 to $200 \mu \mathrm{g} / \mathrm{mL}$ ) and ampicillin showed a concentration of $0.0625 / 8-0.125 / 32 \mu \mathrm{g} / \mathrm{mL}$, while gentamicin showed a concentrations of $4 / 8-128 / 512 \mu \mathrm{g} / \mathrm{mL}$ on tested all bacteria (Table 1 ). The range of $\mathrm{MIC}_{50}$ and $\mathrm{MIC}_{90}$ were from 3.13 to $12.5 \mu \mathrm{g} / \mathrm{mL}$ and 12.5 to $50 \mu \mathrm{g} / \mathrm{mL}$, respectively. The MTEE showed stronger antimicrobial activity against $S$. gordonii (MIC/MBC, $12.5 / 50 \mu \mathrm{g} / \mathrm{mL}$ ) than another bacteria (MIC/MBC, $25 / 50-50 / 200 \mu \mathrm{g} / \mathrm{mL}$ ) and the range of $\mathrm{MIC}_{50}$ and $\mathrm{MIC}_{90}$ were $3.13 \mu \mathrm{g} / \mathrm{mL}$ and $12.5 \mu \mathrm{g} / \mathrm{mL}$.

\section{Synergistic effect of MTEE with antibiotics}

Natural products are a major source of chemical diversity and have provided important treatment agents for many bacterial diseases [16,2729]. The combination of some natural products and antibiotics can increase the antimicrobial activity of antibiotics [30,31]. The synergistic effects of MTEE alone or with antibiotics were evaluated in oral bacteria (Tables 2 and 3). In combination with MTEE, the MIC for ampicillin was reduced $\geq 4$-fold in all tested bacteria, producing a synergistic effect as defined by FICI $\leq 0.5$, except $S$. gordonii by FICI $\leq 0.75$ and additive. The MBC for ampicillin was shown synergistic effects in all tested bacteria by $\mathrm{FBCI} \leq 0.5$, except $S$. ratti, $S$. criceti, and $P$. gingivalis by $\mathrm{FICI} \leq 0.75$ and additive (Table 2 ). In combination with MTEE, the MIC for gentamicin was reduced $\geq 4-8$-fold in all tested bacteria, except $S$. criceti and $P$. gingivalis by FICI $\geq 0.75$ and MBC in all tested bacteria by $\mathrm{FBCI} \leq 0.5$, except $S$. sanguinis, $S$. ratti, S. anginosus, and F. nucleatum by $\mathrm{FBCI} \leq 0.75$ (Table 3 ).

Phytochemical constituents such as alkaloids, flavonoids, tannins, phenols, saponins, and several other aromatic compounds are secondary metabolites of plants that serve a defence mechanism against prediction by many microorganisms, insects and other herbivores [32-35]. Flavonoid complexes attach with extra cellular soluble protein and with bacterial cell wall $[36,37]$. Lignans, alkaloids, flavonoids, butanolides, and essential oils have been derived from M. thunbergii; some of these compounds are antioxidants with hepatoprotective and antibacterial activities $[23,25,26]$. Both the ethyl acetate fraction and water fraction 
Table 1. Antibacterial activity of the Machilus thunbergiii ethanol extract (MTEE) and antibiotics in oral bacteria

\begin{tabular}{|c|c|c|c|c|c|}
\hline \multirow{3}{*}{$\begin{array}{c}\text { Samples } \\
\text { S. mutans } \\
\text { ATCC } 25175^{1}\end{array}$} & \multicolumn{3}{|c|}{$\operatorname{MTEE}(\mu \mathrm{g} / \mathrm{mL})$} & Ampicillin & Gentamicin \\
\hline & $\mathrm{MIC}_{50<}$ & $\mathrm{MIC}_{90<}$ & MIC/MBC & \multicolumn{2}{|c|}{$\mathrm{MIC} / \mathrm{MBC}(\mu \mathrm{g} / \mathrm{mL})$} \\
\hline & 6.25 & 25 & $25 / 100$ & $0.125 / 0.25$ & $8 / 16$ \\
\hline $\begin{array}{l}\text { S. sanguinis } \\
\text { ATCC } 10556\end{array}$ & 12.5 & 50 & $50 / 200$ & $0.25 / 1$ & $16 / 32$ \\
\hline $\begin{array}{l}\text { S. sobrinus } \\
\text { ATCC } 27607\end{array}$ & 6.25 & 25 & $25 / 50$ & $0.0625 / 0.125$ & $16 / 32$ \\
\hline $\begin{array}{c}\text { S. ratti } \\
\text { KCTC } 3294^{2}\end{array}$ & 12.5 & 50 & $50 / 100$ & $0.25 / 0.5$ & $8 / 32$ \\
\hline $\begin{array}{c}\text { S. criceti } \\
\text { KCTC } 3292\end{array}$ & 6.25 & 25 & $25 / 100$ & $0.0625 / 0.125$ & $8 / 16$ \\
\hline $\begin{array}{l}\text { S. anginosus } \\
\text { ATCC } 31412\end{array}$ & 12.5 & 50 & $50 / 200$ & $0.125 / 0.25$ & $8 / 16$ \\
\hline $\begin{array}{c}\text { S. gordonii } \\
\text { ATCC } 10558\end{array}$ & 3.13 & 12.5 & $12.5 / 50$ & $0.125 / 0.5$ & $16 / 32$ \\
\hline $\begin{array}{l}\text { A. actinomycetemcomitans } \\
\text { ATCC } 43717\end{array}$ & 25 & 50 & $50 / 200$ & $8 / 32$ & $8 / 16$ \\
\hline $\begin{array}{l}\text { F. nucleatum } \\
\text { ATCC } 51190\end{array}$ & 6.25 & 25 & $25 / 100$ & $8 / 16$ & $4 / 8$ \\
\hline $\begin{array}{l}\text { P. intermedia } \\
\text { ATCC } 49049\end{array}$ & 12.5 & 50 & $50 / 100$ & $1 / 2$ & $32 / 64$ \\
\hline $\begin{array}{l}\text { P. gingivalis } \\
\text { ATCC } 33277\end{array}$ & 6.25 & 25 & $25 / 50$ & $0.5 / 1$ & $128 / 512$ \\
\hline
\end{tabular}

${ }^{1}$ American Type Culture Collection (ATCC)

${ }^{2}$ Korean collection for type cultures (KCTC)

Table 2. Synergistic effects of Machilus thunbergiii ethanol extract (MTEE) with ampicillin against oral bacteria

\begin{tabular}{|c|c|c|c|c|c|c|}
\hline \multirow{2}{*}{ Strains } & \multirow{2}{*}{ Agent } & \multicolumn{2}{|c|}{$\mathrm{MIC} / \mathrm{MBC}(\mu \mathrm{g} / \mathrm{ml})$} & \multirow{2}{*}{$\mathrm{FIC} / \mathrm{FBC}$} & \multirow{2}{*}{$\mathbf{F I C I} / \mathrm{FBCI}^{2}$} & \multirow{2}{*}{ Outcome } \\
\hline & & Alone & Combination $^{1}$ & & & \\
\hline \multirow{2}{*}{$\begin{array}{c}\text { S. mutans } \\
\text { ATCC } 25175^{3}\end{array}$} & MTEE & $25 / 100$ & $6.25 / 12.5$ & $0.25 / 0.125$ & \multirow{2}{*}{$0.5 / 0.375$} & \multirow{2}{*}{$\begin{array}{l}\text { Synergistic/ } \\
\text { Synergistic }\end{array}$} \\
\hline & Ampicillin & $0.125 / 0.25$ & $0.0313 / 0.0625$ & $0.25 / 0.25$ & & \\
\hline \multirow{2}{*}{$\begin{array}{l}\text { S. sanguinis } \\
\text { ATCC } 10556\end{array}$} & MTEE & $50 / 200$ & $12.5 / 50$ & $0.25 / 0.25$ & \multirow{2}{*}{$0.5 / 0.375$} & \multirow{2}{*}{ Synergistic/ Synergistic } \\
\hline & Ampicillin & $0.25 / 1$ & $0.0625 / 0.125$ & $0.25 / 0.125$ & & \\
\hline \multirow{2}{*}{$\begin{array}{l}\text { S. sobrinus } \\
\text { ATCC } 27607\end{array}$} & MTEE & $25 / 50$ & $6.25 / 12.5$ & $0.25 / 0.25$ & \multirow{2}{*}{$0.5 / 0.5$} & \multirow{2}{*}{ Synergistic/ Synergistic } \\
\hline & Ampicillin & $0.0625 / 0.125$ & $0.0156 / 0.0313$ & $0.25 / 0.25$ & & \\
\hline \multirow{2}{*}{$\begin{array}{c}\text { S. ratti } \\
\text { KCTC } 3294^{4}\end{array}$} & MTEE & $50 / 100$ & $12.5 / 25$ & $0.25 / 0.25$ & \multirow{2}{*}{$0.5 / 0.75$} & \multirow{2}{*}{ Synergistic/ Additive } \\
\hline & Ampicillin & $0.25 / 0.5$ & $0.0625 / 0.25$ & $0.25 / 0.5$ & & \\
\hline \multirow{2}{*}{$\begin{array}{c}\text { S. criceti } \\
\text { KCTC } 3292\end{array}$} & MTEE & $25 / 100$ & $6.25 / 25$ & $0.25 / 0.25$ & \multirow{2}{*}{$0.5 / 0.75$} & \multirow{2}{*}{ Synergistic/ Additive } \\
\hline & Ampicillin & $0.0625 / 0.125$ & $0.0156 / 0.0625$ & $0.25 / 0.5$ & & \\
\hline \multirow{2}{*}{$\begin{array}{l}\text { S. anginosus } \\
\text { ATCC } 31412\end{array}$} & MTEE & $50 / 200$ & $12.5 / 50$ & $0.25 / 0.25$ & \multirow{2}{*}{$0.5 / 0.5$} & \multirow{2}{*}{ Synergistic/ Synergistic } \\
\hline & Ampicillin & $0.125 / 0.25$ & $0.0313 / 0.0625$ & $0.25 / 0.25$ & & \\
\hline \multirow{2}{*}{$\begin{array}{c}\text { S. gordonii } \\
\text { ATCC } 10558\end{array}$} & MTEE & $12.5 / 50$ & $3.13 / 12.5$ & $0.25 / 0.25$ & \multirow{2}{*}{$0.75 / 0.5$} & \multirow{2}{*}{ Additive/ Synergistic } \\
\hline & Ampicillin & $0.125 / 0.5$ & $0.0625 / 0.125$ & $0.5 / 0.25$ & & \\
\hline \multirow{2}{*}{$\begin{array}{c}A . \\
\text { actinomycetemcomitans } \\
\text { ATCC } 43717\end{array}$} & MTEE & $50 / 200$ & $12.5 / 50$ & $0.25 / 0.25$ & \multirow{2}{*}{$0.5 / 0.5$} & \multirow{2}{*}{ Synergistic/ Synergistic } \\
\hline & Ampicillin & $8 / 32$ & $2 / 8$ & $0.25 / 0.25$ & & \\
\hline \multirow{2}{*}{$\begin{array}{l}\text { F. nucleatum } \\
\text { ATCC } 51190\end{array}$} & MTEE & $25 / 100$ & $6.25 / 12.5$ & $0.25 / 0.125$ & \multirow{2}{*}{$0.5 / 0.375$} & \multirow{2}{*}{ Synergistic/ Synergistic } \\
\hline & Ampicillin & $8 / 16$ & $2 / 8$ & $0.25 / 0.5$ & & \\
\hline \multirow{2}{*}{$\begin{array}{l}\text { P. intermedia } \\
\text { ATCC } 49049\end{array}$} & MTEE & $50 / 100$ & $12.5 / 25$ & $0.25 / 0.25$ & $0.5 / 0.5$ & Synergistic/ Synergistic \\
\hline & Ampicillin & $1 / 2$ & $0.25 / 0.5$ & $0.25 / 0.25$ & & \\
\hline P. gingivalis & MTEE & $25 / 50$ & $6.25 / 12.5$ & $0.25 / 0.25$ & $0.5 / 0.75$ & Syneroistic/Additive \\
\hline ATCC 33277 & Ampicillin & $0.5 / 1$ & $0.125 / 0.5$ & $0.25 / 0.5$ & $0.5 / 0.12$ & Synergistic/ Aduitive \\
\hline
\end{tabular}

${ }^{1}$ The MIC and MBC of the Machilus thunbergiii ethanol extract (MTEE) with ampicillin

${ }^{2}$ The fractional inhibitory concentration (FIC) index/fractional bactericical concentration (FBC) index

${ }^{3}$ American Type Culture Collection (ATCC)

${ }^{4}$ Korean collection for type cultures (KCTC)

of M. thunbergii bark and leaf show antimicrobial activity against all the tested Gram-positive bacteria, Staphylococcus aureus were $0.1 \mathrm{mg} /$ $\mathrm{mL}$ and $0.5 \mathrm{mg} / \mathrm{mL}$ [38]. In this study, $M$. thunbergii ethanol extract shows susceptibility on gram-positive bacteria as well as gram-negative bacteria [38].

\section{Time kill of MTEE with antibiotics}

The bacterial effect of MTEE with ampicillin or gentamicin against oral bacteria was confirmed by time-kill curve experiments. The MTEE (MIC or $\mathrm{MIC}_{50}$ ) alone resulted rate of killing increasing or not 
changing in $\mathrm{CFU} / \mathrm{mL}$ at time dependent manner, with a more rapid rate of killing by MTEE $\left(\mathrm{MIC}_{50}\right)$ with ampicillin $\left(\mathrm{MIC}_{50}\right)$ or gentamicin $\left(\mathrm{MIC}_{50}\right)$ (Figures 1-3). A strong bactericidal effect was exerted in drug combinations.
In conclusion, these findings suggest that MTEE fulfills the conditions required of a novel cariogenic bacteria and periodontal pathogens, particularly bacteroides species drug and may be useful in the future in the treatment of oral bacteria.

Table 3. Synergistic effects of Machilus thunbergiii ethanol extract (MTEE) with gentamicin against oral bacteria

\begin{tabular}{|c|c|c|c|c|c|c|}
\hline \multirow{2}{*}{ Strains } & \multirow{2}{*}{ Agent } & \multicolumn{2}{|c|}{ MIC/MBC $(\mu \mathrm{g} / \mathrm{ml})$} & \multirow{2}{*}{ FIC/FBC } & \multirow{2}{*}{ FICI/FBCI ${ }^{2}$} & \multirow{2}{*}{ Outcome } \\
\hline & & Alone & Combination $^{1}$ & & & \\
\hline \multirow{2}{*}{$\begin{array}{l}\text { S. mutans } \\
\text { ATCC } 25175^{3}\end{array}$} & MTEE & $25 / 100$ & $6.25 / 25$ & $0.25 / 0.25$ & \multirow{2}{*}{$0.5 / 0.5$} & \multirow{2}{*}{ Synergistic/ Synergistic } \\
\hline & Gentamicin & $8 / 16$ & $2 / 4$ & $0.25 / 0.25$ & & \\
\hline \multirow{2}{*}{$\begin{array}{l}\text { S. sanguinis } \\
\text { ATCC } 10556\end{array}$} & MTEE & $50 / 200$ & $12.5 / 50$ & $0.25 / 0.25$ & \multirow{2}{*}{$0.5 / 0.75$} & \multirow{2}{*}{ Synergistic/ Additive } \\
\hline & Gentamicin & $16 / 32$ & $4 / 16$ & $0.25 / 0.5$ & & \\
\hline \multirow{2}{*}{$\begin{array}{l}\text { S. sobrinus } \\
\text { ATCC } 27607\end{array}$} & MTEE & $25 / 50$ & $6.25 / 12.5$ & $0.25 / 0.25$ & \multirow{2}{*}{$0.5 / 0.5$} & \multirow{2}{*}{ Synergistic/ Synergistic } \\
\hline & Gentamicin & $16 / 32$ & $4 / 8$ & $0.25 / 0.25$ & & \\
\hline \multirow{2}{*}{$\begin{array}{l}\text { S. ratti } \\
\text { KCTC } 3294^{4}\end{array}$} & MTEE & $50 / 100$ & $12.5 / 50$ & $0.25 / 0.5$ & \multirow{2}{*}{$0.5 / 0.75$} & \multirow{2}{*}{ Synergistic/ Additive } \\
\hline & Gentamicin & $8 / 32$ & $2 / 8$ & $0.25 / 0.25$ & & \\
\hline \multirow{2}{*}{$\begin{array}{l}\text { S. criceti } \\
\text { KCTC } 3292\end{array}$} & MTEE & $25 / 100$ & $12.5 / 25$ & $0.5 / 0.25$ & \multirow{2}{*}{$0.75 / 0.5$} & \multirow{2}{*}{ Additive/ Synergistic } \\
\hline & Gentamicin & $8 / 16$ & $2 / 4$ & $0.25 / 0.25$ & & \\
\hline \multirow{2}{*}{$\begin{array}{l}\text { S. anginosus } \\
\text { ATCC } 31412\end{array}$} & MTEE & $50 / 200$ & $12.5 / 50$ & $0.25 / 0.25$ & \multirow{2}{*}{$0.5 / 0.75$} & \multirow{2}{*}{ Synergistic/ Additive } \\
\hline & Gentamicin & $8 / 16$ & $2 / 8$ & $0.25 / 0.5$ & & \\
\hline \multirow{2}{*}{$\begin{array}{l}\text { S. gordonii } \\
\text { ATCC } 10558\end{array}$} & MTEE & $12.5 / 50$ & $3.13 / 12.5$ & $0.25 / 0.25$ & \multirow{2}{*}{$0.5 / 0.5$} & \multirow{2}{*}{ Synergistic/ Synergistic } \\
\hline & Gentamicin & $16 / 32$ & $4 / 8$ & $0.25 / 0.25$ & & \\
\hline \multirow{2}{*}{$\begin{array}{l}\text { A } \\
\text { actinomycetemcomitans } \\
\text { ATCC } 43717\end{array}$} & MTEE & $50 / 200$ & $12.5 / 25$ & $0.25 / 0.125$ & \multirow[b]{2}{*}{$0.5 / 0.375$} & \multirow[b]{2}{*}{ Synergistic/ Synergistic } \\
\hline & Gentamicin & $8 / 16$ & $2 / 8$ & $0.25 / 0.5$ & & \\
\hline \multirow{2}{*}{$\begin{array}{l}\text { F. nucleatum } \\
\text { ATCC } 51190\end{array}$} & MTEE & $25 / 100$ & $6.25 / 25$ & $0.25 / 0.25$ & \multirow{2}{*}{$0.5 / 0.75$} & \multirow{2}{*}{ Synergistic/ Additive } \\
\hline & Gentamicin & $4 / 8$ & $1 / 4$ & $0.25 / 0.5$ & & \\
\hline \multirow{2}{*}{$\begin{array}{l}\text { P. intermedia } \\
\text { ATCC } 25611\end{array}$} & MTEE & $50 / 100$ & $12.5 / 25$ & $0.25 / 0.25$ & $0.5 / 0375$ & Synerojistic/ Syneroistic \\
\hline & Gentamicin & $32 / 64$ & $8 / 8$ & $0.25 / 0.125$ & & symergistict syntegisuc \\
\hline P. gingivalis & MTEE & $25 / 50$ & $12.5 / 12.5$ & $0.5 / 0.25$ & $0.75 / 0.375$ & Additive/ Synergistic \\
\hline ATCC 33277 & Gentamicin & $128 / 512$ & $32 / 64$ & $0.25 / 0.125$ & $0.12 / 0.3 / 5$ & Adaitive/ synergistic \\
\hline
\end{tabular}

${ }^{1}$ The MIC and MBC of the Machilus thunbergiii ethanol extract (MTEE) with gentamicin

${ }^{2}$ The fractional inhibitory concentration (FIC) index/fractional bactericical concentration (FBC) index

${ }^{3}$ American Type Culture Collection (ATCC)

${ }^{4}$ Korean collection for type cultures (KCTC)
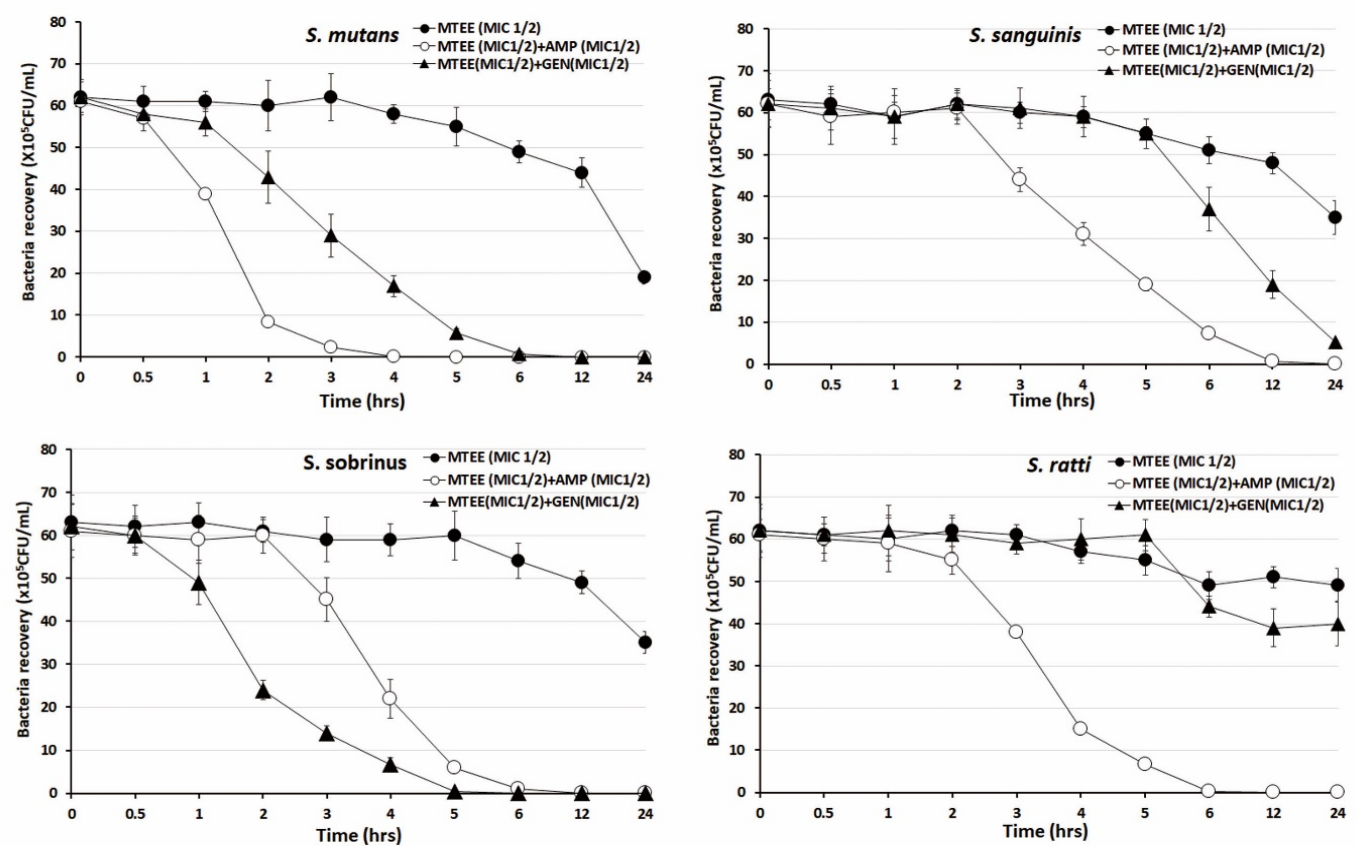

Figure 1. Time-kill curves of MICs of the Machilus thunbergiii ethanol extract (MTEE) alone and in combination with MICs of ampicillin or gentamicin against $S$. mutans, S. sanguinis, $S$. sobrinus, and $S$. ratti. Bacteria were incubated with METK along $(\bullet)$, METK with ampicillin $(\circ)$, and METK with gentamicin $(\boldsymbol{\Delta})$ over time. Data are presented as the mean \pm SD of the four experiments. CFU, colony-forming units 

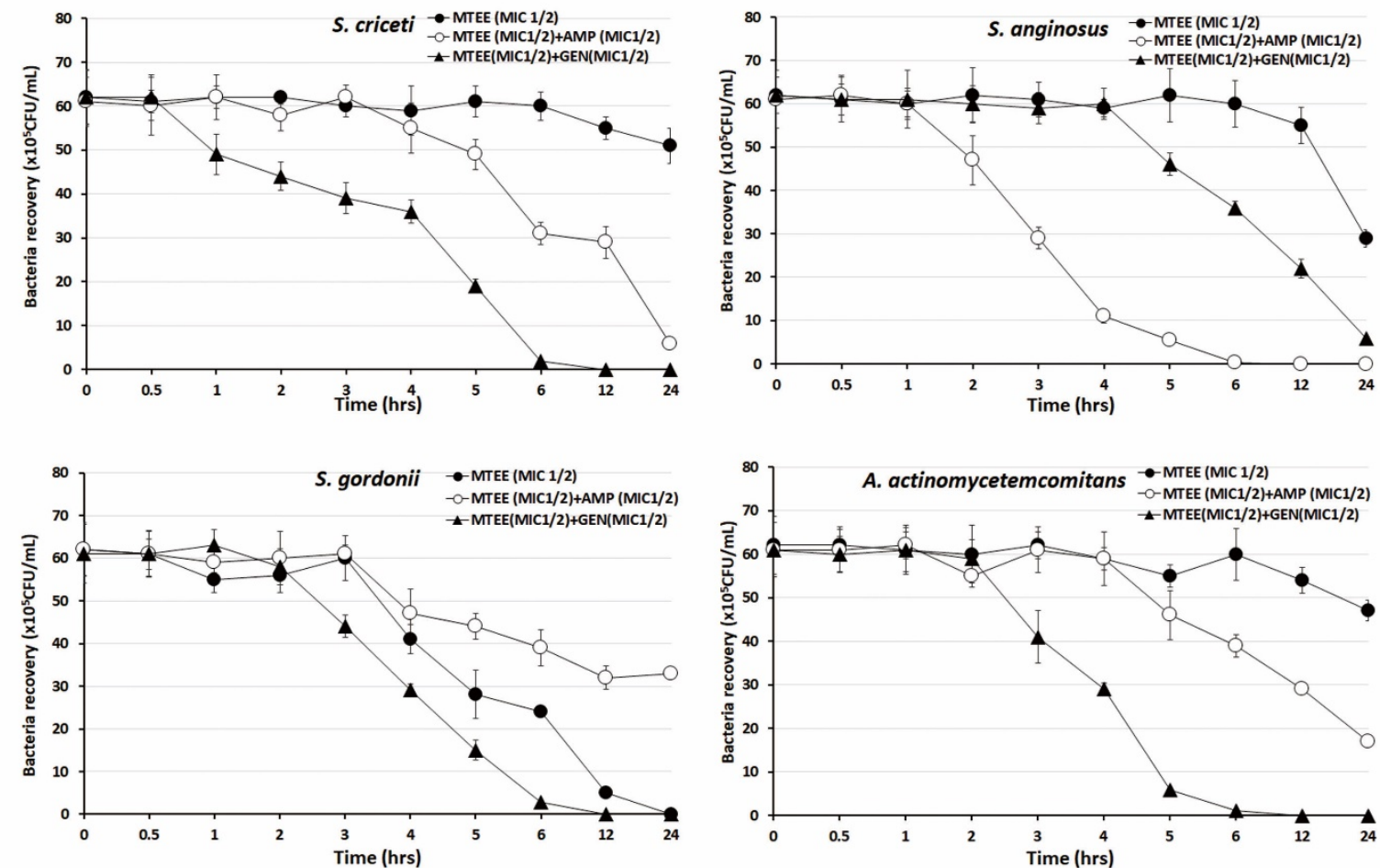

Figure 2. Time-kill curves of MICs of the Machilus thunbergiii ethanol extract (MTEE) alone and in combination with MICs of ampicillin or gentamicin against $S$. criceti, S. anginosus, $S$. gordonii, and $A$. actinomycetemcomitans. Bacteria were incubated with METK along $(\bullet)$, METK with ampicillin $(\circ)$, and METK with gentamicin $(\boldsymbol{\Delta})$ over time. Data are presented as the mean $\pm \mathrm{SD}$ of the four experiments. CFU, colony-forming units
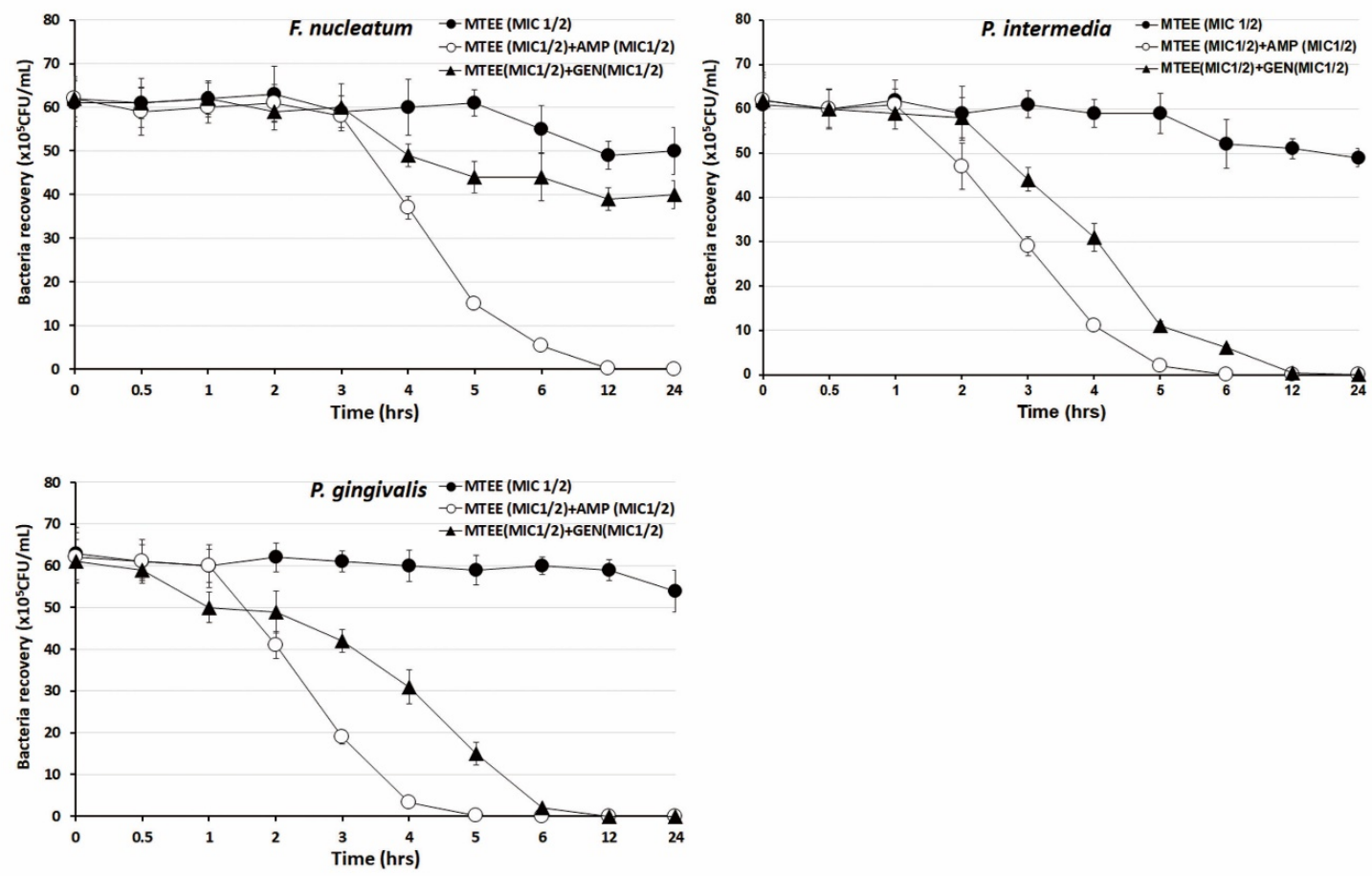

Figure 3. Time-kill curves of MICs of the Machilus thunbergiii ethanol extract (MTEE) alone and its combination with MICs of ampicillin or gentamicin against F. nucleatum, P. intermedia, and $P$. gingivalis. Bacteria were incubated with METK along $(\bullet)$, METK with ampicillin $(\circ)$, and METK with gentamicin $(\boldsymbol{\Delta})$ over time. Data are presented as the mean \pm SD of the four experiments. CFU, colony-forming units 


\section{Declaration of interest}

The authors declare no conflict of interest.

\section{Sources of funding}

This study was not funded by any organization.

\section{Ethical approval}

This study has no need for prior approval by an ethics committee.

\section{References}

1. Costalonga M, Herzberg MC (2014) The oral microbiome and the immunobiology of periodontal disease and caries. Immunol Lett 162: 22-38. [Crossref]

2. Sroussi HY, Epstein JB, Bensadoun RJ, Saunders DP, et al. (2017) Common oral complications of head and neck cancer radiation therapy: mucositis, infections, saliva change, fibrosis, sensory dysfunctions, dental caries, periodontal disease, and osteoradionecrosis. Cancer Med 6: 2918-2931. [Crossref]

3. Chi AC, Neville BW, Krayer JW, Gonsalves WC (2010) Oral manifestations of systemic disease. Am Fam Physician 82: 1381-1388. [Crossref]

4. Kumar PS (2017) From focal sepsis to periodontal medicine: a century of exploring the role of the oral microbiome in systemic disease. J Physiol595: 465-476. [Crossref]

5. Sampaio-Maia B, Caldas IM, Pereira ML, Pérez-Mongiovi D, Araujo R (2016) The Oral microbiome in health and its implication in oral and systemic diseases. Adv Appl Microbiol 97: 171-210. [Crossref]

6. Arweiler NB, Netuschil L (2016) The oral microbiota. Adv Exp Med Biol 902: 45-60. [Crossref]

7. Mickenautsch S, Leal SC, Yengopal V, Bezerra AC, Cruvinel V (2007) Sugar-free chewing gum and dental caries: a systematic review. J Appl Oral Sci 15: 83-88. [Crossref]

8. Morou-Bermudez E, Loza-Herrero MA, Garcia-Rivas V, Suarez-Perez E, Billings RJ (2017) Oral bacterial acid-base metabolism in caries screening: A proof-of-concept study. JDR Clin Trans Res 2: 132-141. [Crossref]

9. Ardila CM, López MA, Guzmán IC (2011) Positive correlations between presence of gram negative enteric rods and Porphyromonas gingivalis in subgingival plaque. Acta odontológica Latinoamericana 24: 15-19.

10. Oliveira RR, Fermiano D, Feres M, Figueiredo LC, Teles FR, et al. (2016) Levels of candidate periodontal pathogens in subgingival biofilm. J Dent Res 95: 711-718.

11. Pinto G, Silva MD, Peddey M, Sillankorva S, Azeredo J (2016) The role of bacteriophages in periodontal health and disease. Future Microbiol 11: 1359-1369. [Crossref]

12. Wu YH, Kuraji R, Taya Y, Ito H, et al. (2018) Effects of theaflavins on tissue inflammation and bone resorption on experimental periodontitis in rats. $J$ Periodontal Res 53: 1009-1019. [Crossref]

13. Kinane DF, Stathopoulou PG, Papapanou PN (2017) Periodontal diseases. Nat Rev Dis Primers 3: 17038. [Crossref]

14. Hienz SA, Paliwal S, Ivanovski S (2015) Mechanisms of bone resorption in periodontitis. J Immunol Res 2015: 615486. [Crossref]

15. Kokoska L, Kloucek P, Leuner O, Novy P (2018) Plant-derived products as antibacterial and antifungal agents in human health care. Curr Med Chem. [Crossref]

16. Sakagami H, Tomomura M (2018) Dental application of natural products. Medicines (Basel) 5. [Crossref]

17. Nabavi SM, Marchese A, Izadi M, Curti V, Daglia M, et al. (2015) Plants belonging to the genus Thymus as antibacterial agents: from farm to pharmacy. Food Chem 173: 339-347. [Crossref]

18. Santhosh RS, Suriyanarayanan B (2014) Plants: a source for new antimycobacterial drugs. Planta Med 80: 9-21. [Crossref]

19. Ma CJ, Kim YC, Sung SH (2009) Compounds with neuroprotective activity from the medicinal plant Machilus thunbergii. J Enzyme Inhib Med Chem 24: 1117-1121.

20. Lee MK, Yang H, Ma CJ, Kim YC (2007) Stimulatory activity of lignans from Machilus thunbergii on osteoblast differentiation. Biol Pharm Bull 30: 814-817.
21. Kim SJ, You J, Choi HG, Kim JA, Jee JG, et al. (2015) Selective inhibitory effects of machilin A isolated from Machilus thunbergii on human cytochrome P450 1A and 2B6. Phytomedicine 22: 615-620.

22. Li L, Shi H, Zhang S, Hu T, Wang J, et al. (2018) First report of lasiodiplodia gilanensis causing twig and leaf blight on machilus thunbergii in zhejiang province of China. Plant Dis.

23. Su YC, Hsu KP, Li SC, Ho CL (2015) Composition, in vitro cytotoxicity, and antimildew activities of the leaf essential oil of machilus thunbergii from Taiwan. Nat Prod Commun 10: 2013-2016. [Crossref]

24. Pan LY, Chen WN, Chiu ST, Raman A, Chiang TC, et al. (2015) Is a gall an extended phenotype of the indicing insect? A comparative study of selected morphological and physiological traits of leaf and stem galls on Machilus thunbergii (Lauraceae) induced by five species of daphnephila (Diptera: Cecidomyiidae) in northeastern Taiwan. Zoolog Sci 32: 314-321.

25. Yu YU, Kang SY, Park HY, Sung SH, Lee EJ, et al. (2000) Antioxidant lignans from Machilus thunbergii protect CC14-injured primary cultures of rat hepatocytes. J Pharm Pharmacol 52: 1163-1169.

26. Kim NY, Ryu JH (2003) Butanolides from Machilus thunbergii and their inhibitory activity on nitric oxide synthesis in activated macrophages. Phytother Res 17: 372-375.

27. Cha JD, Jeong MR, Jeong SI, Lee KY (2007) Antibacterial activity of sophoraflavanone $\mathrm{G}$ isolated from the roots of Sophora flavescens. J Microbiol Biotechnol 17: 858-864.

28. Vieweg L, Reichau S, Schobert R, Leadlay PF, Süssmuth RD (2014) Recent advances in the field of bioactive tetronates. Nat Prod Rep 31: 1554-1584. [Crossref]

29. Diefenbach AL1, Muniz FWMG1, Oballe HJR1, Rösing CK1 (2018) Antimicrobial activity of copaiba oil (Copaifera ssp.) on oral pathogens: Systematic review. Phytother Res 32: 586-596. [Crossref]

30. Hemaiswarya S, Kruthiventi AK, Doble M (2008) Synergism between natural products and antibiotics against infectious diseases. Phytomedicine 15: 639-652.

31. Ma XH, Zheng CJ, Han LY, Xie B, Jia J, et al. (2009) Synergistic therapeutic actions of herbal ingredients and their mechanisms from molecular interaction and network perspectives. Drug Discov Today 14: 579-588

32. Politeo O, Skocibusic M, Carev I, Burcul F, Jerkovic I, et al. (2012) Phytochemical profiles of volatile constituents from Centaurea ragusina leaves and flowers and their antimicrobial effects. Nat Prod Commun 7: 1087-1090.

33. Wright B, Spencer JP, Lovegrove JA, Gibbins JM (2013) Insights into dietary flavonoids as molecular templates for the design of anti-platelet drugs. Cardiovasc Res 97: 13-22. [Crossref]

34. Mishra BB, Tiwari VK (2011) Natural products: an evolving role in future drug discovery. Eur J Med Chem 46: 4769-4807. [Crossref]

35. Yamamoto H, Ogawa T (2002) Antimicrobial activity of perilla seed polyphenols against oral pathogenic bacteria. Biosci Biotechnol Biochem 66: 921-924.

36. Yusook K, Weeranantanapan O, Hua Y, Kumkrai P, Chudapongse N (2017) Lupinifolin from Derris reticulata possesses bactericidal activity on Staphylococcus aureus by disrupting bacterial cell membrane. J Nat Med 71: 357-366. [Crossref]

37. La VD, Labrecque J, Grenier D (2009) Cytoprotective effect of proanthocyanidin-rich cranberry fraction against bacterial cell wall-mediated toxicity in macrophages and epithelial cells. Phytother Res 23: 1449-1452.

38. Seo KS, Yun KW (2018) Comparative evaluation of antimicrobial and antioxidant potential of bark and leaf of magnolia obovata THUNB. and Machilus thunbergii S. et Z. J Pharm Sci Res 10: 528-531.

Copyright: (C)2018 Jang E. This is an open-access article distributed under the terms of the Creative Commons Attribution License, which permits unrestricted use, distribution, and reproduction in any medium, provided the original author and source are credited. 